\title{
Automated Purification of Radiometals Produced by Liquid Targets
}

\author{
Vítor H. Alves ${ }^{1, *(0)}$, Sérgio J. C. do Carmo ${ }^{1}\left(\mathbb{D}\right.$, Francisco Alves ${ }^{2}$ and Antero J. Abrunhosa $^{2}{ }^{\mathbb{C}}$ \\ 1 ICNAS-Produção, University of Coimbra, Pólo das Ciências da Saúde, Azinhaga de Santa Comba, \\ 3000-548 Coimbra, Portugal; sergiocarmo@uc.pt \\ 2 ICNAS, University of Coimbra, Pólo das Ciências da Saúde, Azinhaga de Santa Comba, \\ 3000-548 Coimbra, Portugal; franciscoalves@uc.pt (F.A.); antero@pet.uc.pt (A.J.A.) \\ * Correspondence: vitoralves@uc.pt; Tel.: +351-239-488-510
}

Received: 13 August 2018; Accepted: 12 September 2018; Published: 14 September 2018

\begin{abstract}
An automated process for the production and purification of radiometals produced by irradiating liquid targets in a medical cyclotron, using a commercially available module, has been developed. The method is suitable for the production and purification of radiometals such as ${ }^{68} \mathrm{Ga}$, ${ }^{64} \mathrm{Cu}$ and ${ }^{61} \mathrm{Cu}$ through irradiation of liquid targets and is important for producing high specific activity radioisotopes with a substantial reduction in processing time and cost when compared with the solid target approach. The "liquid target" process also eliminates the need for pre- and post-irradiation target preparation and simplifies the transfer of irradiated material from target to hotcell. $\mathrm{A}^{68} \mathrm{GaCl}_{3}$ solution can be obtained in about $35 \mathrm{~min}$ with an average yield of $73.9 \pm 6.7 \%$ in less than $10 \mathrm{~mL}$ of volume. ${ }^{64} \mathrm{CuCl}_{2}$ solutions can be obtained with an average yield of $81.2 \pm 7.8 \%$ in about $1 \mathrm{~h}$ of processing time. A dedicated single-use disposable kit is used on a commercial IBA Synthera ${ }^{\circledR}$ extension module.
\end{abstract}

Keywords: liquid targets; medical cyclotron; radiometals; gallium-68; copper-64; copper-61; purification; disposable kit; radiopharmaceuticals

\section{Introduction}

The interest of radiometals in Nuclear Medicine has increased dramatically over the last decade fostered by the successful clinical use of metal-based radiopharmaceuticals in combined targeted diagnosis and therapy (the so-called theragnostic concept) [1-5]. To produce these radiometals, most hospitals would require the purchase of isotope generators, when available, or to make a substantial investment in a medical cyclotron with a solid target system. This is not a trivial option as most cyclotrons typically handle liquid and gas targets only and are used to produce non-metallic isotopes such as ${ }^{18} \mathrm{~F},{ }^{11} \mathrm{C}$ and ${ }^{13} \mathrm{~N}$. Therefore, the possibility to produce metal isotopes using a medical cyclotron without the investment in a solid-target system provides an easy and accessible way to produce these isotopes within a wide range of accelerator facilities [6-11]. Recent developments concerning the production of radiometals using liquid targets have been published by our group [12,13], paving the way for a new, safer and simplified procedure for automated loading and transfer of target solution to an automated chemistry module inside of a shielded hot-cell, and helping compliance with current Good Manufacturing Practices (GMP) regulations [10].

The methods described allow the production of radioisotopes-such as ${ }^{68} \mathrm{Ga},{ }^{64} \mathrm{Cu},{ }^{61} \mathrm{Cu}$ and others-through the irradiation of liquid targets, with a substantial reduction in processing time and cost when compared with the solid target approach. The process also eliminates the need for pre- and post-irradiation target preparation and simplifies the transfer of irradiated material from target to hotcell (Figure 1). 


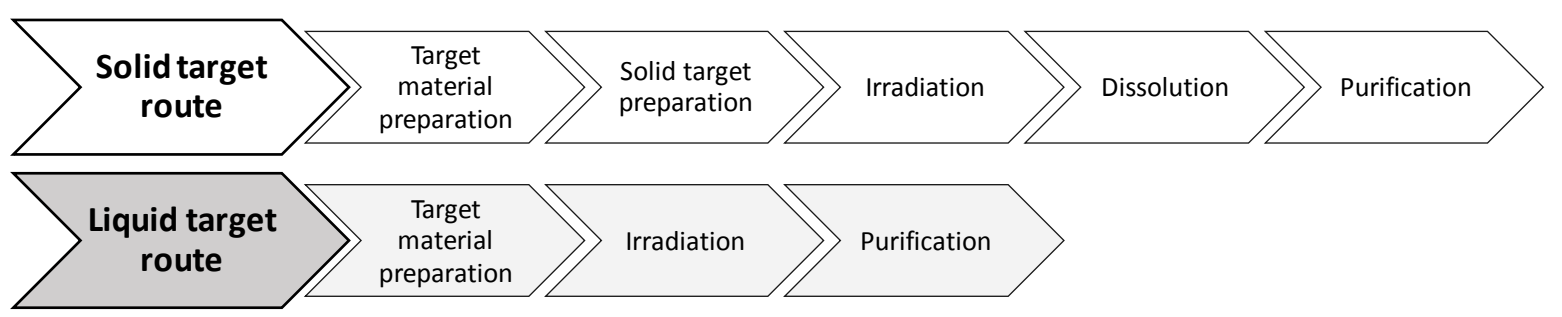

Figure 1. Solid and liquid routes to produce radiometals in a medical low energy cyclotron.

Based on the potential of fast and cost-effective production of radiometals in medical cyclotrons, we present a fully automated process, using a commercially available module, for the purification of metal radioisotopes produced by cyclotron irradiation of liquid targets. This work describes the fully automated separation of ${ }^{68} \mathrm{Ga}$ and ${ }^{64} \mathrm{Cu}$ or ${ }^{61} \mathrm{Cu}$ from target material and formulation in a solution for radiolabelling in compliance with European Pharmacopoeia (Ph. Eur.) requirements [14]. The purified chloride solution can be used for labelling molecules using a conventional automated procedure in a reactor vial followed by post purification by a C18 cartridge [15-17] or by means of a cold-kit based method [18-20].

The process described can easily be extended to other metal radioisotopes. Irradiation of liquid targets in medical cyclotrons involves the previous preparation of a target solution containing the enriched (when needed) material in a process that benefits from the high yields provided by the same nuclear reactions used in the solid target while avoiding the inherent limitations of using such targets. In addition to the post-irradiation handling and transport of the solid target to a processing unit (shielded hotcell), such solid targets require a large amount of expensive enriched material (hundreds of mg are necessary) and such a long and complicated process is also associated with inevitable contamination with other metal ions due to the use of higher volumes of strong acids for the dissolution.

\section{Materials and Methods}

All steps required for the production and separation of a metal radioisotope from a liquid target are implemented in a fully integrated system. For each isotope, a dedicated IBA Nirta Conical ${ }^{\circledR}$ target system (IBA, Louvain-la-Neuve, Belgium) is used. To separate the metal isotopes from the target solution and reformulate them in a ready-to-use chloride solution, a commercially available IBA Synthera ${ }^{\circledR}$ Extension module (IBA, Louvain-la-Neuve, Belgium) is used with single-use kits. For the radiolabelling step, an IBA Synthera ${ }^{\circledR}$ Extension is used to label compounds with ${ }^{64} \mathrm{Cu} /{ }^{61} \mathrm{Cu}$ (e.g., bis(4-methyl-3-thiosemicarbazone), PTSM; diacetyl-2,3-bis(N4-methyl-3-thiosemicarbazone), ATSM) and an IBA Synthera@ for ${ }^{68}$ Ga-based compounds (e.g., 1,4,7,10-tetraazacyclododecane-1,4,7,10-tetraacetic acid (DOTA) peptides, $N, N^{\prime}$-bis(2-hydroxybenzyl)ethylenediamine- $N, N^{\prime}$-diacetic acid (HBED) peptides. For metal trace analysis of samples, is used an inductively coupled plasma mass spectrometry (ICP-MS) equipment: Thermo Scientific iCAP Qc (Thermo Fisher Scientific, Waltham, MA, USA). To measure the activities of samples, an ISOMED 2010 (Nuklear-medizintechnik, Dresden, Germany) is used.

All chemicals and solvents used are trace-metal grade.

\subsection{Targetry/Irradiation}

As target material, the enriched isotopes are diluted in a $0.01 \mathrm{M}$ nitric acid solution (Table 1). Concentrations are adjusted to produce a maximum of required activity while avoiding precipitation and providing stability of the solution over time for storage and better behaviour under the cyclotron beam without corrosion of target support materials $[6,7]$. 
Table 1. Composition of various solutions used.

\begin{tabular}{cccc}
\hline Isotope & Target Material & Reaction & Chemical form Solution \\
\hline Gallium-68 $\left({ }^{68} \mathrm{Ga}\right)$ & Zinc-68 $\left({ }^{68} \mathrm{Zn}\right)-{ }^{\mathrm{A}} \mathrm{E}=99.5 \%$ Enrich. & ${ }^{68} \mathrm{Zn}(\mathrm{p}, \mathrm{n}){ }^{68} \mathrm{Ga}$ & ${ }^{68} \mathrm{Zn}\left(\mathrm{NO}_{3}\right)_{2} \cdot 6 \mathrm{H}_{2} \mathrm{O}$ \\
Copper-64 $\left({ }^{64} \mathrm{Cu}\right)$ & Nickel-66 $\left({ }^{64} \mathrm{Ni}\right)-95 \%$ Enrich. & ${ }^{64} \mathrm{Ni}(\mathrm{p}, \mathrm{n}){ }^{64} \mathrm{Cu}$ & ${ }^{64} \mathrm{Ni}_{\left(\mathrm{NO}_{3}\right)_{2} \cdot 6 \mathrm{H}_{2} \mathrm{O}}$ \\
Copper-61 $\left({ }^{61} \mathrm{Cu}\right)$ & Natural Zinc $\left({ }^{\text {nat }} \mathrm{Zn}\right)$ & ${ }^{n a t} \mathrm{Zn}(\mathrm{p}, \alpha)^{61} \mathrm{Cu}$ & ${ }^{n a t} \mathrm{Zn}\left(\mathrm{NO}_{3}\right)_{2} \cdot 6 \mathrm{H}_{2} \mathrm{O}$ \\
\hline
\end{tabular}

${ }^{64} \mathrm{Ni}$ and ${ }^{68} \mathrm{Zn}$ targets are typically irradiated with a beam current of about $70 \mu \mathrm{A}$ and $45 \mu \mathrm{A}$, respectively, using an IBA 18/9 Cyclone cyclotron. The amount of enriched material on target varies from $10-100 \mathrm{mg}$ of ${ }^{64} \mathrm{Ni}$ and $100-400 \mathrm{mg}$ of ${ }^{68} \mathrm{Zn}$, depending on the required activity. After irradiation, solutions are transferred to a processing hot-cell under nitrogen pressure.

\subsection{Post-Processing}

For the Gallium-68 production, the irradiated ${ }^{68} \mathrm{Zn}$ target solution is dissolved multiple times in water and the solution is passed through a cation exchange resin (SCX; DOWEX 50W, 200-400 mesh, $\mathrm{H}+$ form, treated with $10 \mathrm{~mL}$ of $3 \mathrm{M} \mathrm{HCl}$ followed by $10 \mathrm{~mL}$ of water) loaded on a $1 \mathrm{~mL}$ catridge. The cartridge is then washed with $30 \mathrm{~mL}$ of Acetone/ $\mathrm{HBr}$ mixture to remove zinc ions as described by Strelow [21,22]. The adsorbed ${ }^{68} \mathrm{Ga}$ cations are eluted from the SCX cartridge with $6 \mathrm{~mL}$ of $\mathrm{HCl} 3 \mathrm{M}$ mixed with $10 \mathrm{~mL}$ of $\mathrm{HCl} 30 \%$ (to increase the molarity of $\mathrm{HCl}$ ) to an intermediate reservoir (Figure 2) and passed through an anion exchange resin (SAX; Biorad AG1 100 mesh, treated with $10 \mathrm{~mL}$ of water followed by $10 \mathrm{~mL}$ of $\mathrm{HCl} 8 \mathrm{M}$ ) loaded on $0.5 \mathrm{~mL}$ size-cartridge where the anionic complex $\left[{ }^{68} \mathrm{GaCl}_{4}\right]^{-}$ remained strongly adsorbed $[23,24]$. A flow of inert gas is then applied to dry the column and remove any traces of $\mathrm{HCl}$. Finally, ${ }^{68} \mathrm{Ga}$ is eluted from the column with water into a final collection vial in the form of ${ }^{68} \mathrm{GaCl}_{3}$ solution in $0.1-0.25 \mathrm{M} \mathrm{HCl}$. The ${ }^{68} \mathrm{Zn}$ ions are collected on a separate vial and can be recycled to be reused as target material.

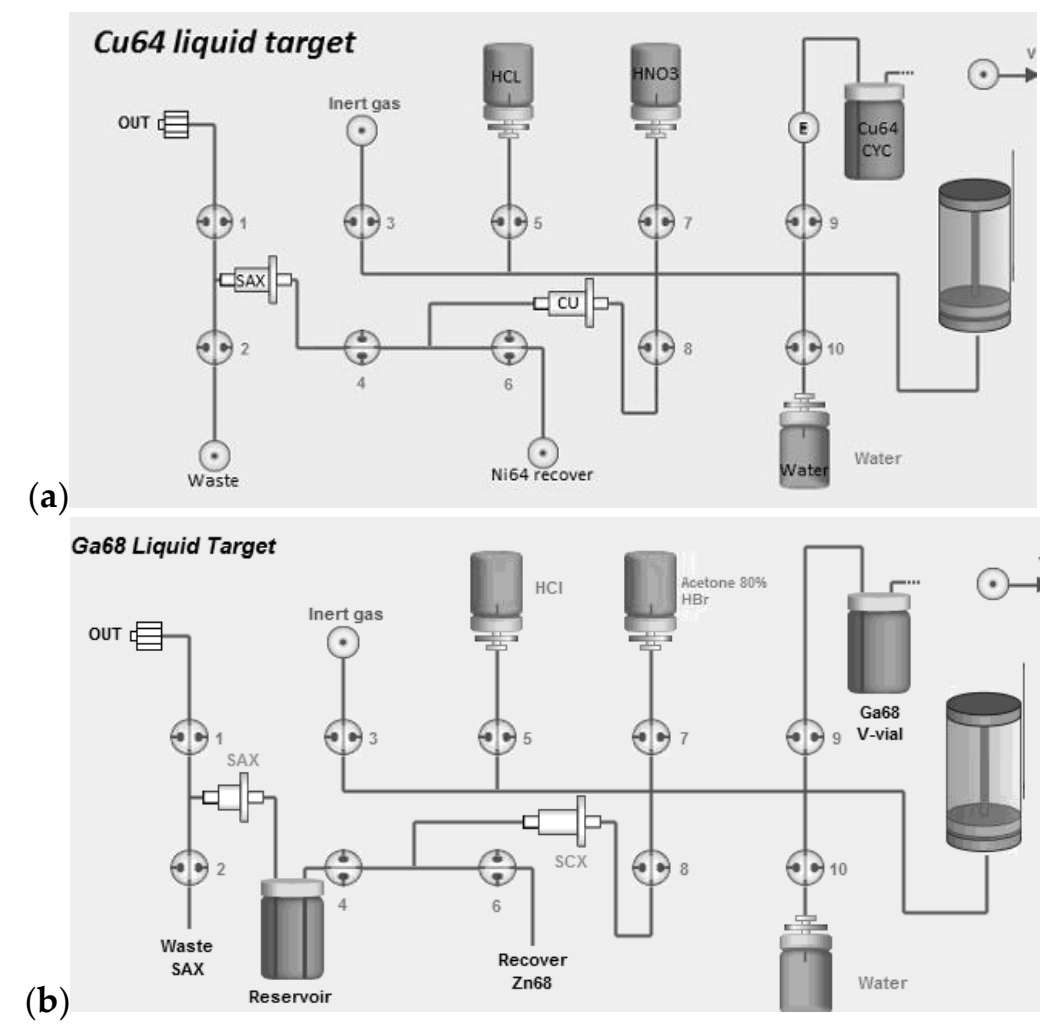

Figure 2. Schematic diagram of IBA Synthera ${ }^{\circledR}$ Extension synthesizer software to purify and prepare ${ }^{64} \mathrm{Cu} /{ }^{61} \mathrm{Cu}$-chloride solution (a) and to purify and prepare ${ }^{68} \mathrm{Ga}$-chloride solution (b). 
The entire purification process takes about $35 \mathrm{~min}$ from end of bombardment (EOB).

Conversely, for the production of copper radioisotopes $\left({ }^{61} \mathrm{Cu}\right.$ and $\left.{ }^{64} \mathrm{Cu}\right)$ the irradiated ${ }^{\text {nat }} \mathrm{Zn}$ or ${ }^{64} \mathrm{Ni}$ liquid target solution is dissolved multiple times in water to bring the $\mathrm{pH}$ to a suitable range for the adsorption of the copper ions onto a highly selective $\mathrm{Cu}$ resin (TrisKem International, Bruz, France) loaded on $2 \mathrm{~mL}$ cartridge, as described by Dirks [25]. The $\mathrm{pH}$ adjusted solution is then passed through the resin (pre-conditioned with $10 \mathrm{~mL}$ of water) that is then washed with $10 \mathrm{~mL}$ of $\mathrm{HNO}_{3}$ $1 \mathrm{mM}$ to remove any traces of non-copper ions. The adsorbed ${ }^{64} \mathrm{Cu} /{ }^{61} \mathrm{Cu}$ cations are eluted from the cartridge with $5 \mathrm{~mL}$ of $\mathrm{HCl} 3 \mathrm{M}$, directly to an anion exchange resin (SAX; TrisKem International, treated with $10 \mathrm{~mL}$ of water followed by $10 \mathrm{~mL}$ of $\mathrm{HCl} 8 \mathrm{M}$ ) (Figure 2) loaded on $0.5 \mathrm{~mL}$ cartridge size where the anionic complex $\left[{ }^{64} \mathrm{CuCl}_{4}\right]^{-} /\left[{ }^{61} \mathrm{CuCl}_{4}\right]^{-}$remains strongly adsorbed. A flow of inert gas is then applied to dry the column and remove any traces of $\mathrm{HCl}$. Finally, copper is eluted from the column with water into a final collection vial in the form of a copper chloride solution. In the case of ${ }^{64} \mathrm{Cu}$ production, ${ }^{64} \mathrm{Ni}$ ions are recovered on a separated vial and can be recovered to be recycled. As for ${ }^{\text {nat }} \mathrm{Zn}$, there is no need to recover, as natural zinc is quite inexpensive.

The entire purification process takes about $1 \mathrm{~h}$ from EOB.

\subsection{Specific Activity and Trace Metal Analysis}

Specific activities $(\mathrm{TBq} / \mu \mathrm{g})$ of ${ }^{68} \mathrm{Ga}$ and ${ }^{64} \mathrm{Cu}$ were calculated by measuring the total $\mathrm{Ga}$ and $\mathrm{Cu}$ present in the final chloride solution after purification using inductively coupled plasma mass spectrometry (ICP-MS). Other metal contaminants including $\mathrm{Al}, \mathrm{Co}, \mathrm{Cu}, \mathrm{Ga}, \mathrm{Fe}, \mathrm{Ni}$ and $\mathrm{Zn}$ were also analysed by ICP-MS.

\section{Results}

Figure 3 shows the successful separation of ${ }^{68} \mathrm{Ga},{ }^{61} \mathrm{Cu}$ and ${ }^{64} \mathrm{Cu}$ from their target nuclides using the methods described. The presented procedure for processing radiometals is able to recover $81.2 \pm 7.8 \%$ ( $n=10$, average of 10 runs) of Copper- 64 chloride solution in a small volume $(4 \mathrm{~mL})$ using the cartridge-based purification with a disposable kit on a commercial IBA Synthera ${ }^{\circledR}$ extension module. Using an almost identical process, we recovered $73.9 \pm 6.7 \%$ ( $n=33$, average of 33 runs) of Gallium-68 chloride solution in $5-10 \mathrm{~mL}$ of volume using the ionic exchange principle applied on the same synthesizer module with a dedicated disposable tubing kit. The efficiency of our separation (Figure 3) is consistent with the previously reported purification yields $[7,9,26]$.

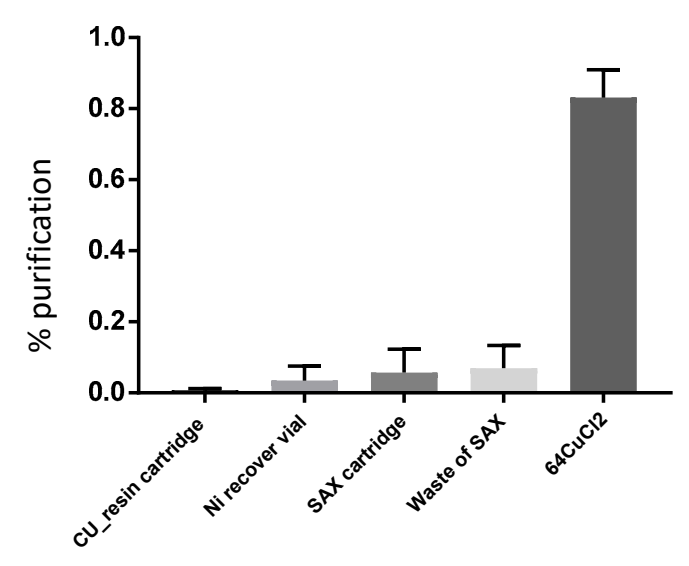

(a)

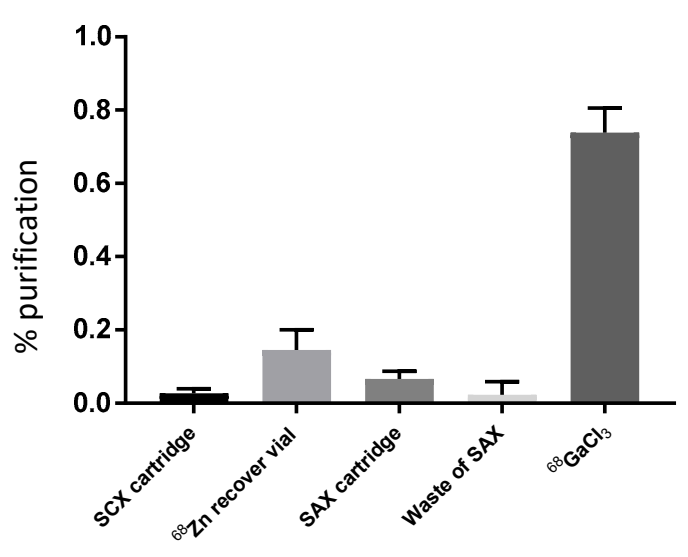

(b)

Figure 3. Average yields and activity loss in each step. Purification of ${ }^{64} \mathrm{CuCl}_{2}$ (a), with $81.2 \pm 7.8 \%$ (decay corrected) yield in $1 \mathrm{~h}$ of process. Purification of ${ }^{68} \mathrm{GaCl}_{3}(\mathbf{b})$, with $73.9 \pm 6.7 \%$ (decay corrected) yield in $35 \mathrm{~min}$ of process. 
Average production yields and respective specific molarities are summarized on Table 2. In Figure 4, the results of ICP-MS analysis for determination of metal impurities in final solutions are presented.

Table 2. Purified activities obtained and respective specific activity.

\begin{tabular}{ccccc}
\hline Isotope & $\begin{array}{c}\text { Target Material } \\
\text { Amount }\end{array}$ & $\begin{array}{c}\text { Irradiation and } \\
\text { Purification Time }\end{array}$ & $\begin{array}{c}\text { Activity at End of } \\
\text { Purification (EOP) (GBq) }\end{array}$ & $\begin{array}{c}\text { Specific Activity } \\
\text { (TBq/ug) }\end{array}$ \\
\hline Gallium-68 & $100 \mathrm{mg}$ & $1 \mathrm{~h} 35 \mathrm{~min}$ & $1.5-2.7$ & $0.3-24\left({ }^{68} \mathrm{Ga} / \mathrm{Ga}\right)$ \\
& $200 \mathrm{mg}$ & $1 \mathrm{~h} 35 \mathrm{~min}$ & $4.4-5.1$ & $0.3-24\left({ }^{68} \mathrm{Ga} / \mathrm{Ga}\right)$ \\
Copper-64 & $10-100 \mathrm{mg}$ & $1 \mathrm{~h} 30 \mathrm{~min}-9 \mathrm{~h} 30 \mathrm{~min}$ & $0.54-4.6$ & $5.0-122.8\left({ }^{64} \mathrm{Cu} / \mathrm{Cu}\right)$ \\
\hline
\end{tabular}

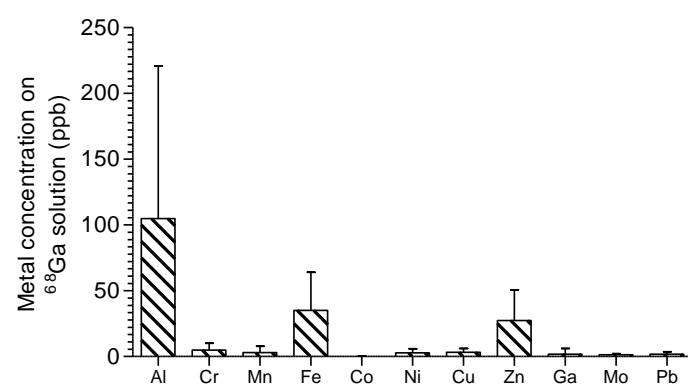

(a)

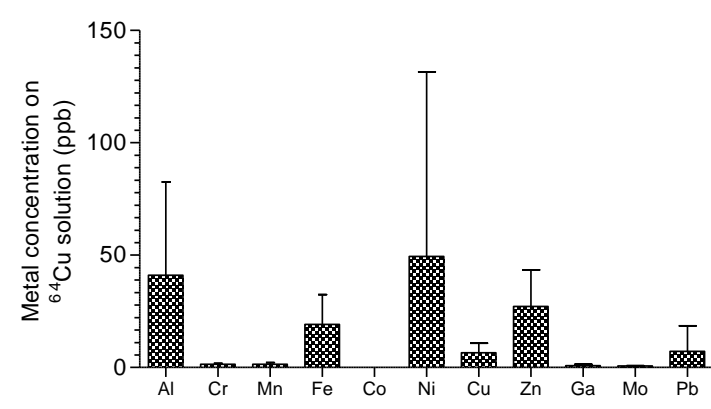

(b)

Figure 4. Concentration of $\mathrm{Ga},{ }^{64} \mathrm{Cu}$ and other contaminants in the final product solution. Final volume: $10 \mathrm{~mL}$ for $\mathrm{Ga}$ and $4 \mathrm{~mL}$ for $\mathrm{Cu}$. (number of values $n=25$ for $\mathrm{Ga}(\mathbf{a})$ and $n=3$ for $\mathrm{Cu}(\mathbf{b})$ ).

${ }^{68} \mathrm{Ga}$ solutions produced were tested for the presence of iron and zinc using ICP-MS. Results are shown in Figure 5 and are in accordance with the Ph. Eur. requirement of a maximum of $10 \mu \mathrm{g} / \mathrm{GBq}[14]$ up to $4 \mathrm{~h}$ after the end of purification.

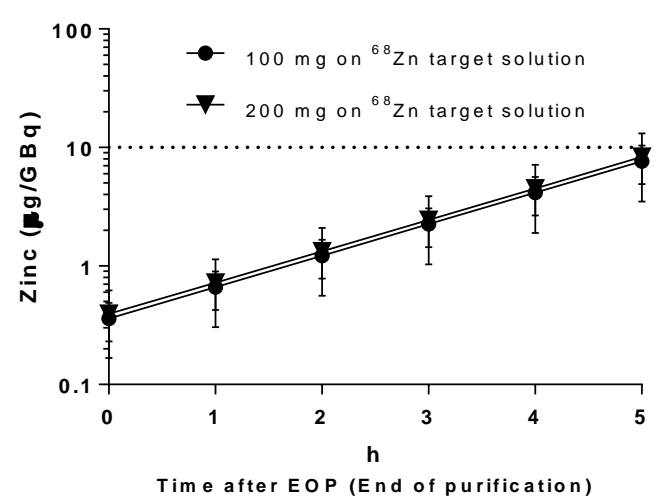

(a)

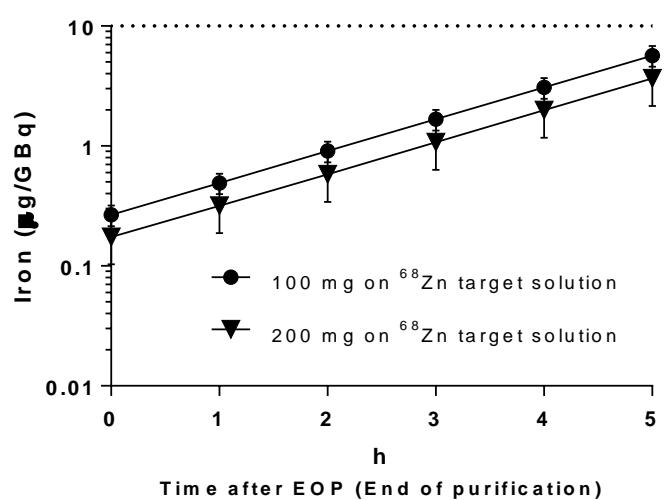

(b)

Figure 5. Chemical purity of final ${ }^{68} \mathrm{Ga}$-peptide formulation. The product complies with the Ph. Eur. regarding the maximum amount in $\mu \mathrm{g}$ of Zinc (a) and Iron (b) per GBq of activity. Values are decay corrected.

An iTLC analysis was made for all chloride solutions to confirm the presence of the ionic forms of the radiometal isotopes and the absence of colloidal complexes (Figure 6). 


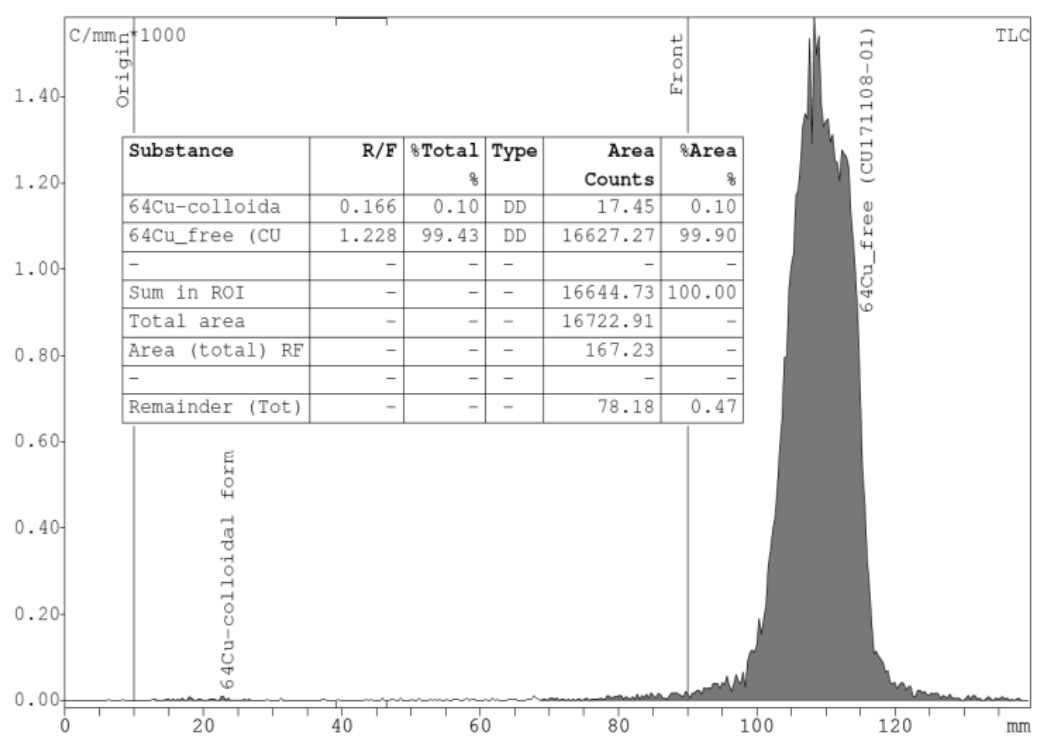

(a)

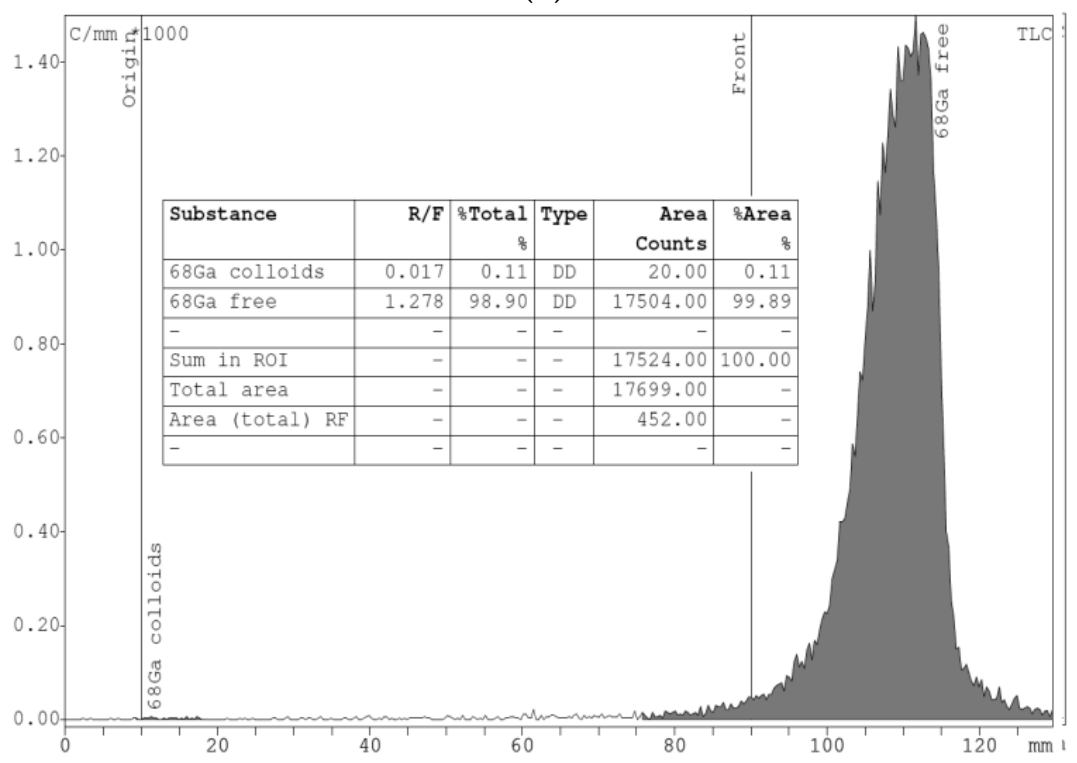

(b)

Figure 6. iTLC analysis of purified ${ }^{64} \mathrm{CuCl}_{2}$ (a) and ${ }^{68} \mathrm{GaCl}_{3}$ (b) using a Raytest miniGita detector. Stationary phase: iTLC-SG strips; mobile phase: $0.1 \mathrm{M}$ sodium citrate (pH adjusted to 4-4.5). $\mathrm{Rf}=0.1-0.2$ for colloidal form and $\mathrm{Rf}=1.0$ for free radioisotope.

\section{Discussion}

A complete setup for radiometal production and purification based on the irradiation of a liquid target was implemented using an IBA target and an IBA Synthera ${ }^{\circledR}$ Extension module. Using commercially available disposable kits (Fluidomica, Coimbra, Portugal) the system is able to recover $81.2 \pm 7.8 \%$ of copper- 64 chloride solution for radiolabelling in less than one hour of processing time, and $73.9 \pm 6.7 \%$ of gallium- 68 chloride solution for radiolabelling in less than $35 \mathrm{~min}$ processing time. The activity of ${ }^{68} \mathrm{Ga}$ lost to zinc-68 recover vial is explained with amount of SCX resin used on first purification step. It was decided to keep this to ensure the proper clean of zinc ions from resin without increasing the volume of washing solution and subsequent increasing of processing time. This is a significant improvement, with less processing time and considerably lower costs, when compared with a conventional solid target system [27] or the published results from other liquid target systems [11,26]. The approach described here enables the production of purified radiometal solutions ready to be used 
for labelling radiopharmaceuticals for human use with final activities large enough for multiple doses and/or for distribution to other positron emission tomography (PET) facilities.

Specific activities were in the range of $0.3-24 \mathrm{TBq} / \mu \mathrm{g}$ for ${ }^{68} \mathrm{Ga}$ and $5.0-122.8 \mathrm{TBq} / \mu \mathrm{g}$ for ${ }^{64} \mathrm{Cu}$. The presence of metal contaminants, especially iron and zinc, were very low and in compliance with the Ph. Eur. regarding the maximum amount permitted per GBq of activity in the final product vial. As Figure 4 shows, for gallium and copper purification processes, it was found in the final chloride solutions, some traces (part per billion level) of aluminium that was explained by the glass storage container, and iron coming from all the reagents used by the "concentration" effect of process once iron has the same behavior of gallium and will be 'carried' together with to final purified solutions. Zinc presence on gallium- 68 and copper-61 chloride solutions can be observed in small concentration at end once are the start target material. The same is said for nickel on copper-64 purification. The zinc present on copper-64 chloride solution was not explained and was assumed as possible contamination from used reagents.

Since the amount of expensive enriched material can be chosen and optimized to suit the requirements for each production, a very substantial cost reduction is achieved when compared to the solid target technique. The purified radiometal solution is ready to be used for radiolabelling in about $30 \mathrm{~min}$ for ${ }^{68} \mathrm{Ga}$ and $1 \mathrm{~h}$ for ${ }^{64} \mathrm{Cu}$ after EOB which is a significant improvement considering the inevitable time-consuming post-irradiation processing associated with the solid target technique.

This improvement is even more important for the case of ${ }^{68} \mathrm{Ga}$ where the purity of the product is maintained for up to $5 \mathrm{~h}$ after EOB. When compared with generator obtained ${ }^{68} \mathrm{Ga}$, two major advantages emerged: (1) it is possible to make more consecutive runs as only $1 \mathrm{~h} 35 \mathrm{~min}$ is necessary to produce ${ }^{68} \mathrm{GaCl}_{3}$, from the beginning of irradiation till the end of purification, compared with the generators' ${ }^{68} \mathrm{Ga}$-grown waiting time and (2) no risk of contamination with long-lived impurities, as occurs with ${ }^{68} \mathrm{Ge} /{ }^{68} \mathrm{Ga}$ generators, where there is a significant risk of ${ }^{68} \mathrm{Ge}$ breakthrough.

\section{Conclusions}

The described process makes feasible the production of metal radioisotopes, such as ${ }^{68} \mathrm{Ga}$, ${ }^{64} \mathrm{Cu}$ and ${ }^{61} \mathrm{Cu}$, through the irradiation of a liquid target, using a medical cyclotron, with a considerable reduction in processing time and cost when compared with the traditional solid target approach. The process also eliminates the complex and time-consuming tasks associated with preand post-irradiation target preparation and simplifies the transfer of irradiated material from target to hot-cells.

Additionally, the automated process with disposable cassettes reduces radiation exposure to the operator, improves robustness of the production and provides documentation of the manufacturing process that can be used to fulfil GMP requirements.

Considering that virtually all medical cyclotrons installed worldwide are using liquid targets for routine production of PET radiopharmaceuticals, this approach provides an easier and accessible way to produce medical radioisotopes for human use in a wide range of accelerator facilities.

\section{Patents}

EP20150170854. Process for producing gallium-68 through the irradiation of a solution target. (Grant 2017-08-09; Publication 2017-08-09)

US15172905. Process for producing gallium-68 through the irradiation of a solution target. (Pending).

Author Contributions: Conceptualization, V.H.A.; Data curation, V.H.A.; Formal analysis, V.H.A.; Investigation, V.H.A.; Methodology, V.H.A.; Project administration, F.A. and A.J.A.; Resources, S.J.C.d.C., F.A. and A.J.A.; Supervision, F.A. and A.J.A.; Validation, F.A. and A.J.A.; Visualization, V.H.A.; Writing-original draft, V.H.A.; Writing-review \& editing, F.A. and A.J.A.

Funding: This research received no external funding.

Conflicts of Interest: The authors declare no conflict of interest. 


\section{References}

1. Yordanova, A.; Feldmann, G.; Ahmadzadehfar, H.; Essler, M.; Eppard, E.; Kürpig, S.; Schönberger, S.; Gonzalez-Carmona, M.; Feldmann, G.; Ahmadzadehfar, H.; et al. Theranostics in Nuclear Medicine Practice. Preprints 2017, 2017010094. [CrossRef]

2. Velikyan, I. Prospective of ${ }^{68}$ Ga-radiopharmaceutical development. Theranostics 2013, 4, 47-80. [CrossRef] [PubMed]

3. Velikyan, I. Continued rapid growth in ${ }^{68} \mathrm{Ga}$ applications: Update 2013 to June 2014. J. Label. Compd. Radiopharm. 2015, 58, 99-121. [CrossRef] [PubMed]

4. Brasse, D.; Nonat, A. Radiometals: Towards a new success story in nuclear imaging? Dalt. Trans. 2015, 44, 4845-4858. [CrossRef] [PubMed]

5. Cutler, C.S.; Hennkens, H.M.; Sisay, N.; Huclier-Markai, S.; Jurisson, S.S. Radiometals for combined imaging and therapy. Chem. Rev. 2013, 113, 858-883. [CrossRef] [PubMed]

6. Do Carmo, S.J.C.; Alves, V.; Alves, F.; Abrunhosa, A.J. Fast and cost-effective cyclotron production of ${ }^{61} \mathrm{Cu}$ using a ${ }^{\text {nat }} \mathrm{Zn}$ liquid target: An opportunity for radiopharmaceutical production and R\&D. Dalt. Trans. 2017, 46, 14556-14560. [CrossRef]

7. Alves, F.; Alves, V.H.P.; Do Carmo, S.J.C.; Neves, A.C.B.; Silva, M.; Abrunhosa, A.J. Production of copper-64 and gallium-68 with a medical cyclotron using liquid targets. Mod. Phys. Lett. A 2017, 32, 1740013. [CrossRef]

8. Hoehr, C.; Badesso, B.; Morley, T.; Trinczek, M.; Buckley, K.; Klug, J.; Zeisler, S.; Hanemaayer, V.; Ruth, T.R.; Benard, F.; et al. Producing radiometals in liquid targets: Proof of feasibility with 94mTc. AIP Conf. Proc. 2012, 1509, 56-60. [CrossRef]

9. Hoehr, C.; Oehlke, E.; Hou, X.; Zeisler, S.; Adam, M.; Ruth, T.; Buckley, K.; Celler, A.; Benard, F.; Schaffer, P. Production of Radiometals in a Liquid Target. Available online: http://hzdr.qucosa.de/api/qucosa\% 3A22237/attachment/ATT-0/ (accessed on 13 September 2018).

10. Alves, F.; Alves, V.H.; Neves, A.C.B.; do Carmo, S.J.C.; Nactergal, B.; Hellas, V.; Kral, E.; Gonçalves-Gameiro, C.; Abrunhosa, A.J.; Gonçalves-gameiro, C.; et al. Cyclotron production of Ga-68 for human use from liquid targets: From theory to practice. AIP Conf. Proc. 2017, 1845, 20001-20005. [CrossRef]

11. Oehlke, E.; Hoehr, C.; Hou, X.; Hanemaayer, V.; Zeisler, S.; Adam, M.J.; Ruth, T.J.; Celler, A.; Buckley, K.; Benard, F.; et al. Production of Y-86 and other radiometals for research purposes using a solution target system. Nucl. Med. Biol. 2015, 42, 842-849. [CrossRef] [PubMed]

12. Abrunhosa, A.; Alves, V.; Alves, F. Process for Producing Gallium-68 Through the Irradiation of a Solution Target 2016. U.S. Patent US15172905, 7 December 2016.

13. Alves, V.H.; Abrunhosa, A.J.; Alves, F. Process for Producing Gallium-68 Through the Irradiation of a Solution Target 2015. U.S. Patent EP20150170854, 5 June 2015.

14. European Pharmacopeia. Gallium $\left({ }^{68} \mathrm{Ga}\right)$ Chloride Solution for Radiolabelling. Available online: https: / / www.edqm.eu/sites/default/ files / content-list-90.pdf (accessed on 13 September 2018).

15. Alves, V.H.; Prata, M.I.M.; Abrunhosa, A.J.; Castelo-Branco, M. GMP production of ${ }^{68}$ Ga-labelled DOTA-NOC on IBA Synthera. J. Radioanal. Nucl. Chem. 2015. [CrossRef]

16. Ocak, M.; Antretter, M.; Knopp, R.; Kunkel, F.; Petrik, M.; Bergisadi, N.; Decristoforo, C. Full automation of ${ }^{68} \mathrm{Ga}$ labelling of DOTA-peptides including cation exchange prepurification. Appl. Radiat. Isot. 2010, 68, 297-302. [CrossRef] [PubMed]

17. Matarrese, M.; Bedeschi, P.; Scardaoni, R.; Sudati, F.; Savi, A.; Pepe, A.; Masiello, V.; Todde, S.; Gianolli, L.; Messa, C.; et al. Automated production of copper radioisotopes and preparation of high specific activity $\left[{ }^{64} \mathrm{Cu}\right] \mathrm{Cu}-\mathrm{ATSM}$ for PET studies. Appl. Radiat. Isot. 2010, 68, 5-13. [CrossRef] [PubMed]

18. Mukherjee, A.; Pandey, U.; Chakravarty, R.; Sarma, H.D.; Dash, A. Development of single vial kits for preparation of ${ }^{68} \mathrm{Ga}$-labelled peptides for PET imaging of neuroendocrine tumours. Mol. Imaging Biol. 2014, 16, 550-557. [CrossRef] [PubMed]

19. Ma, M.T.; Cullinane, C.; Waldeck, K.; Roselt, P.; Hicks, R.J.; Blower, P.J. Rapid kit-based (68)Ga-labelling and PET imaging with THP-Tyr(3)-octreotate: A preliminary comparison with DOTA-Tyr(3)-octreotate. EJNMMI Res. 2015, 5, 52. [CrossRef] [PubMed] 
20. Asti, M.; Iori, M.; Capponi, P.C.; Rubagotti, S.; Fraternali, A.; Versari, A. Development of a simple kit-based method for preparation of pharmaceutical-grade ${ }^{68}$ Ga-DOTATOC. Nucl. Med. Commun. 2015, 36, 502-510. [CrossRef] [PubMed]

21. Strelow, F.W. Quantitative separation of gallium from zinc, copper, indium, iron(III) and other elements by cation-exchange chromatography in hydrobromic acid-acetone medium. Talanta 1980, 27, 231-236. [CrossRef]

22. Van der Walt, T.N.; Strelow, F.W.E. Quantitative Separation of Gallium from Other Elements by Cation-Exchange Chromatography. Anal. Chem. 1983, 55, 212-216. [CrossRef]

23. Velikyan, I. Synthesis, Characterization and Application of Ga-Labelled Peptides and Oligonucleotides; Licentiate Dissertation, Institute of Chemistry, Department of Organic Chemistry: Uppsala, Sweden, 2004.

24. Meyer, G.J.; Macke, H.; Schuhmacher, J.; Knapp, W.H.; Hofmann, M. ${ }^{68}$ Ga-labelled DOTA-derivatised peptide ligands. Eur. J. Nucl. Med. Mol. Imaging 2004, 31, 1097-1104. [CrossRef] [PubMed]

25. Dirks-Fandrei, C. Entwicklung von Methoden zur Selektiven Trennung von Scandium, Zirkonium und Zinn für Radiopharmazeutische Anwendungen; Philipps-Universität Marburg: Marburg, Germany, 2014; p. 20.

26. Pandey, M.K.; Byrne, J.F.; Jiang, H.; Packard, A.B.; DeGrado, T.R. Cyclotron production of (68)Ga via the $(68) \mathrm{Zn}(\mathrm{p}, \mathrm{n})(68) \mathrm{Ga}$ reaction in aqueous solution. Am. J. Nucl. Med. Mol. Imaging 2014, 4, 303-310. [PubMed]

27. Malinconico, M.; Asp, J.; Lang, C.; Boschi, F.; Guidi, G.; Takhar, P. Radiometals Production by Only One Solid Target System. Available online: https:/ / www.comecer.com/radiometals-production-by-only-onesolid-target-system/ (accessed on 10 July 2018).

(C) 2018 by the authors. Licensee MDPI, Basel, Switzerland. This article is an open access article distributed under the terms and conditions of the Creative Commons Attribution (CC BY) license (http://creativecommons.org/licenses/by/4.0/). 